\title{
ESTUDIOS
}

\section{Las sirenas de Sarhua}

\author{
LUIS MILIONES \\ Universidad Nacional Mayor de San Marcos \\ HIROYASU TOMOEDA \\ Universidad de Hiroshima
}

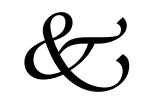

\section{Restmen}

\begin{abstract}
El presente artículo es producto de una investigación sobre uno de los motivos més llamativos y recurrentes en las Tablas de Sarhua: la sirena. Real izamos una aproximación a este motivo, que originalmente aparece en la literatura clásica occidental, con la finalidad de explicar las razones de su presencia en el arte andino. Para tal efecto transcribimos algunos testimonios que, desde una cosmovisión netamente andina, dan cuenta de una serie de creencias vinauladas con el ámbito musical, en el que las sirenas juegan un papel central.
\end{abstract}

Palabras claves: Tablas de Sarhua, sirena, arte andino, música andina.

\section{Introducción}

- Cuáles son los caminos que recorre la imaginación europea para Cenraizarse en América? ¿Cómo selecciona la sociedad indígena aquellos elementos extraños a su historia que luego incorpora como suyos? Cuando podamos responder a estas preguntas, sabremos la 
manera en que la sirena, personaje inseparable de los paisajes marinos de Occidente, ha llegado a chapotear en las lagunas y ríos de los Andes.

No las trata bien la mitología griega. Son la contraparte maligna de las musas, mientras éstas desarrollan sus artes para deleite de los hombres y dioses, las sirenas cantan y seducen, pero para devorar a los hombres que están al alcance de su voz. No existe episodio más conocido en la literatura universal que las angustias de Odiseo cuando decide escuchar el canto de las sirenas, para evitar su hechizo. Circe le dijo:

\footnotetext{
"Aquel que imprudentemente se acerca a ellas y oye su voz, ya no vuelve a ver a su esposa, ni a sus hijos pequeñuelos rodeándole llenos de júbilo, cuando toma a sus hogares, sino que le hechizan las sirenas con el sonoro canto, sentadas en una pradera y teniendo alrededor [un] enorme montón de huesos de hombres putrefactos cuya piel se va consumiendo. Pasa de largo pero tapa las orejas de tus compañeros con cera blanda, previamente adelgazada, a fin de que ninguno las oiga, mas si tú desearas oírlas, haz que te aten a la velera embarcación de pies y manos, derecho y arrimadb a la parte inferior del mástil, y que las sogas te liguen al mismo; y así podrás deleitarte escuchando a las sirenas. Y [en] caso de que supliques o mandes a los compañeros que te suelten, átente con más lazos todavía" (Homero 1956: 269-270) .
}

De acuerdo con la descripción de Homero, las sirenas aparecen "sentadas en una pradera", no tienen la forma consagrada por la iconografía pasterior con la parte inferior del cuerpo en forma de pez. Más bien son aves rapaces con cara de mujer que devoran a los hombres, que al ser atraídos por su canto, desembarcan en las orillas de su territorio. Su canto, además, no promete sensualidad alguna:
" ¡Ea, célebre Odiseo, gloria insigne de los aqueos! Acércate y detén la nave para que oigas nuestra voz. Nadie ha pasado en su negro bajel sin que oyera la suave voz que fluye de nuestra boca, sino que se van después de recrearse con ella, sabiendo más que antes, pues sabemos cuántas fatigas padecieron en la vasta Troya argivos y teucros, por la voluntad de los dioses y conocemos, también, toob cuanto ocurre en la fértil tierra" (Homero 1956: 275-276) .

Estas son las palabras que no pudieron escuchar los marineros, y que tentaban sin efecto a odiseo, que no podía zafarse de sus ligaduras. Nótese que el ofrecimiento concreto de las sirenas es de conocimiento, las voces de ellas amuncian a quien se les acerque, que ganará "sabiendo 
más que antes" , promesa que nos recuerda la tentación de la serpiente a Adán y Evva en el Paraíso Terrenal.

Al revés de las musas que suelen asociarse con Febo, el dios del sol y la vitalidad, las sirenas aparecen vinculadas al mundo inferior. Una tradición recogida siglos después por Ovidio, las hace servidoras de Ceres, curya hija Proserpina había sido raptada por Hades (el Plutón de los romanos) . Luego de una búsqueda inútil, su fracaso sirve para explicar el tránsito de criaturas del aire a seres marinos. Su asociación con la muerte y el mundo interior, adonde se resignó a vivir Proserpina, es evidente por la conducta de las sirenas, dispuestas a atraer y devorar a quienes fascinan con su canto. En palabras del poeta de Sulmona, ciudad del Abruzzo Citerior, la transformación es narrada así:

\begin{abstract}
"¿De dónde as provienen las plumas y los pies de ave cuando tenéis un rostro de virgen? ¿O por qué cuando Proserpina recogía las flores primaverales, as hallasteis entre el número de sus compañeras, o doctas sirenas? Después de que buscasteis en vano por todo el mundo, al instante, para que el mar se diera cuenta de nuestra inquietud, deseasteis poder sosteneros sobre las aguas con los remos de vuestras alas y tuvisteis propicios a los dioses y visteis que vuestros miembros se cubrieron de pronto de amarillo plumaje. Mas para que vuestros cantos melodiosos, nacidos para recrear los oídos y aquel don extraordinario de vuestra boca no se perdiera, as quedó el rostro de doncella y la voz humana" (Ovidio 1991: 111).
\end{abstract}

Con la conversión al cristianismo, se divulga la imagen y simbología de los peces como seres justos. Y aunque apenas se le menciona en el Antiguo Testamento, esta representación se multiplica en los evangelios, sobre todo a raíz de la promesa que Cristo ofrece a sus apóstoles: "Yo os haré pescadores de hombres" (Mateo 4:19; Marcos 1: 17; Lucas 5: 10).

Esta percepción que adopta la Europa cristiana tiene consecuencias en la imagen de la sirena. Mientras que el Salvador pesca, es decir, rescata a sus fieles de las incertidumbres del mundo (representado por el océano) , la sirena los arrastra hacia el fondo del mar que equivale al infiemo. Esto no quiere decir que desapareciese de la arquitectura o esculturas cristianas; al contrario, su presencia se multiplica con el arte románico entre los siglos VI y XII especialmente en Francia. Cabe destacar que su representación marina (con cola de pez) desplaza lentamente a la de ave rapaz, y que los intentos de condenar su figura 
ya no se basan en la vieja tradición homérica. Aparte de la consideración demoníaca, el tratado sobre la cultura occidental que compuso Isidoro de Sevilla tiene una reflexión que no sólo rechaza la versión greco romana, más aun, compone una mirada racionalizante de lo que a su juicio pudieron ser seres que intimidaron a Odiseo:

\begin{abstract}
"A las sirenas, que eran tres, se las imagina con un cuerpo mitad de doncella, mitad de pájaro, dotadas de alas y uñas; una de ellas cantaba consuvoz, ctra con su flauta, y la tercera con la lira, con su canto atraían a los navegantes fascinados, que eran arrastrados al naufragio. Pero lo cierto es que fueron unas meretrices que llevaban a la nuina a quienes pasaban, y éstos se veían después en la necesidad de simular que habían naufragado. Se dice que tenían alas y uñas, porque el amor vuela y causa heridas; y que vivían en las olas, porque precisamente las olas crearcna Venus" (Isidbro 1994: II. 53).
\end{abstract}

La reflexión de Isidoro, que podríamos fechar alrededor del año 620 de nuestra era, pone énfasis en la fascinación sexual atribuida a las sirenas, sean o no personajes de la realidad. Situación que contrasta con la inexistencia de los órganos sexuales femeninos que corresponderían a su parte de pez, lo que acentúa la falsedad de las promesas de amor que las creencias populares atribuyen a su canto. Esta relación de sirena con el peligro de lo oculto, alcanzó a teñir otros caminos de la imaginación. En la Francia medieval, la difundida leyenda de la Melusina, la pinta en ocasiones en forma de sirena, aunque la tradición, escrita entre otros por Jean d'Arras, no tenga nada en común con los personajes de Homero u Ovidio.

La reflexión de San Isidoro no pasó desapercibida. En 1556 cuando se publica por primera vez Ie immagini con la spositione dei dei de gli antichi, raccolte per Vicenzo Cartari, en Venecia, ya se luscan explicaciones más creíbles a los accidentes o matanzas causados por tales seres. El propio Cartari recogió la versión de que "las fábulas griegas fingían la existencia de las sirenas como pájaros con bellas caras de mujer, que cantaban dulcemente. Pero en realidad fueron ciertos escollos escondidas por las ondas del mar, que al golpear en ellos creaban un murmullo suave, que los navegantes entretenidos por su dulzura, pasaban sobre ellos, pereciendo miserablemente" (Cartari 1996: 267-270) .

Medio siglo antes, Jeroen Anthoniszoon van Aeken, conocido como Hieronymus Bosch, había colocado una sirena en "El jardín de las 
delicias", el famoso tríptico celebrado por Felipe II. El Bosco decidió fundir en una imagen las dos tradiciones en las que se asentaba la sirena, y si bien la dibuja -en azul- con medio cuerpo de pez y montada sobre otro animal marino, los hace surcar los cielos, dotando de alas al pez que la lleva en la parte superior del cuenpo central del tríptico que descansa en el Museo del Prado.

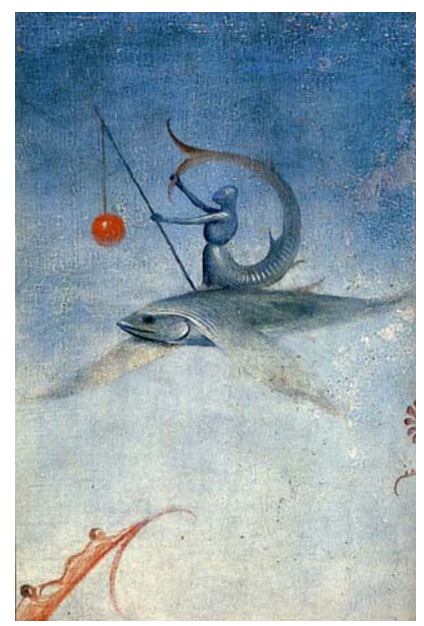

\section{Las sirenas en los mares de América}

Las sirenas sorprendieron a Cristóbal colón el miércoles 9 de enero de 1493: "El día pasado, cuando el Almirante iba al río del Oro, dijo que vido tres sirenas que salieron bien alto de la mar, pero no eran tan hermosas como las pintan, que en alguna manera tenían forma de hombre en la cara. Dijo también que otras veces vido algunas en Guinea, en la costa de Manegueta". (Durand 1983: 27) .

Esta visión, que se suele atribuir a la rápida mirada y a la imaginación de don Cristóbal, se ha interpretado como el asomar habitual de los manatíes. La recopilación de éste y otros incidentes, componen el libro sabroso de José Durand. Pero no fue sólo Colón, quien pensó que las sirenas revivían en América, haciéndose parte de la fauna de monstruos que resucitó en el Renacimiento. El mismo Durand desentierra a Marco 
Guazzo que, al relatar el viaje del futuro Felipe II a Génova en 1548, incluía en su abultado equipaje "tres sátiros recién llegados de las Indias, el uno de diez y el otro de cuarenta años, y una hembra; y también una sirena, pero muerta" (1983: III) . No sabemos si fueron monos o manatíes los que realmente acompañaron al que pronto sería rey de España, pero queda clara la voluntad de encontrar a nuestro personaje en el Nuevo Mundo.

Uno de los lugares propicios para que esto suceda tenía que ser el lago Titicaca. Esta enorme superficie de agua salobre tenía ya las valencias religiosas que le otorgaban las civilizaciones precolombinas. El lago era la pakarina por excelencia de los reinos que florecieron en sus orillas y finalmente del Tawantinsuyu, que en su mito de origen explicaba que la pareja fundadora brotó de sus profundidades.

Así lo ha sugerido Teresa Gisbert (1984: 45-46). Apoyándose en el diccionario de Ludovico Bertonio y en el cronista Alonso Ramos Gavilán, muestra lo que pudo haber sido el encuentro de la tradición europea de las sirenas con las diosas femeninas del lago. Se trata de las hermanas Quesintur y Umantur, con quienes había pecado el dios Tumupa. Ambas era lo que Gisbert llama mujeres-peces y las relaciona con "una señora muy hermosa" que acompañó a Santo Tomás (a quien los cronistas identifican como el Tumupa de los indígenas). Teresa Gisbert supone que la dama pudo haber salido de las aguas y que es otra versión de las mismas diosas precolombinas del lago.

Como dijimos al empezar este trabajo, siempre será difícil establecer las razones por las que las culturas andinas seleccionan determinados elementos de la propuesta europea, que les llegan dentro o fuera de la misión evangelizadora. ¿Por qué son sirenas las que pueblan los lagos y ríos de las alturas andinas, y no hay tritones, nereidas o sátiros? Ia posibilidad que explora Gisbert es interesante y corresponde a una búsqueda en la mitología precolombina de personajes similares. Pero por encima de que tal coincidencia pudiera haber ocurrido en el collao, nos queda por explicar si las funciones que cumplía la sirena en el universo europeo, son similares a su contraparte andina. Podría ser que la criatura importada desde España no necesitara afirmarse en ninguna de las que proporcionaba el panteón americano, pero dadas las condiciones planteadas por el proceso colonial se hizo necesaria su 
incorporación. Las razones todavía están por ser estudiadas, pero la etnografía nos presenta pistas que parecen estar guiadas por la importancia de la música. Como se sabe, coros, canciones, instrumentos, etc. , tuvieron formidable despliegue en el proceso de cristianización. Pero tal invasión de sonidos, y la forma de producirlos, llegaba a una sociedad que también era musical y tenía miles de años de crear y ejercer dicho arte.

A la Iglesia, las habilidades de los músicos andinos le produjo sensaciones encontradas. De una parte, era necesario tener profesionales y personal entrenado, y también jóvenes o niños que supiesen del arte a través de su familia o de su comunidad. Por otra parte, había que censurar y prohibir las manifestaciones (canto y baile) que a su juicio fuesen pecaminosas. Ahora sabemos que la capacidad de los sacerdotes coloniales para catequizar los espacios y las gentes de América fue muy limitada. Hubo tiempo y lugares, como los hay en nuestros días, en los que la presencia real del clero era mínima o inexistente. La música, sin embargo, cubre con o sin evangelización, todo espacio habitado, y en las áreas de mayor concentración indígena, se constituyen reductos ideológicos donde sonidos e instrumentos han establecido conductas que, sin reflexionar sobre sus orígenes, satisfacen las necesidades de la sociedad contemporánea.

La sirena siempre aparece asociada a este complejo de acciones musicales. Pasaremos revista a la información que nos proporcionan la historia y la etnografía andinas en la que se menciona a las sirenas de manera específica.

\section{Sirenas de altura}

Su primera aparición como ilustración se encuentra en la crónica de Felipe Guaman Poma de Ayala. En el folio 316 (Adorno 1980: 289) se aprecia dos mujeres que están cantando dentro del río Huatanay, con medio cuerpo fuera del agua, mientras señalan con sus dedos índices a dos jóvenes que están sentados en la cima de un cerro, tocando un instrumento de viento. Los jóvenes miran hacia ellas desde Pingollanapa (terraza de los pinkullos, en la traducción de Urioste) . Guaman Poma no las llama sirenas, aunque el dibujo no replica la 
forma conocida por Occidente, el cuerpo entero es de mujer, pero la mitad inferior está dentro del agua.

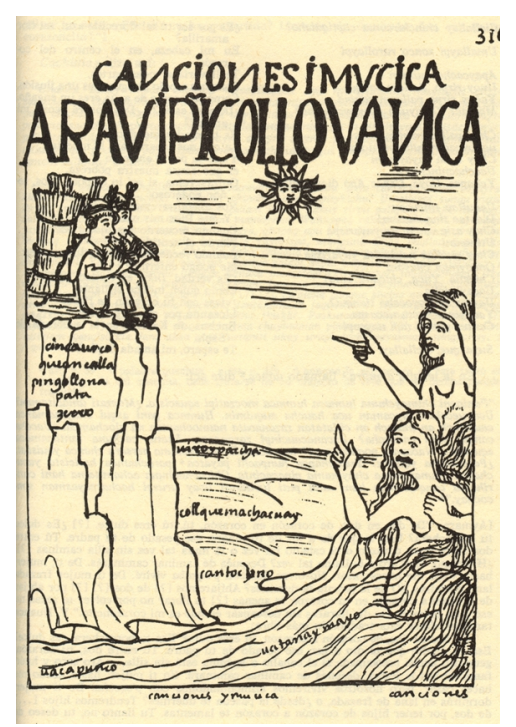

Posteriormente el mismo autor, al dibujar el Mapamundi del Reino de las Indias en los folios 983-984 (Adomo, 1980:914-915) coloca en la parte superior izquierda, debajo de la representación de la luna, a una sirena como parte de los seres marinos que viven en el océano, que rodea la tierra recién descubierta.

Las dos figuras pueden relacionarse con el dibujo de los sarhuinos, la que aparece en el mapamundi es una versión más de la que rondaba en la imaginación de los ayacuchanos. Pero más interesante es aquella en que las sirenas interactúan con los dos jóvenes: lo hacen a través de la música. Ellas cantan acompañando a los músicos andinos.

Los ayacuchanos, como en otras partes de la sierra andina, creen en la existencia de sirenas, que habiendo abandonado el mar, moran en los ríos y lagunas, en especial al lado de las cascadas o cataratas, a las que llaman pacchas. Así las dibujan los pintores de Sarhua, como se aprecia en la "tabla", que ilustra este artículo, una caída de agua ocupa el centro del cuadro al que flanquean las cinco sirenas. La parte inferior 
del cuerpo de estos seres se identifica con el pez trucha, que también aparece dibujado alternando con las sirenas. Curiosamente, la introoucción de este animal es muy tardía y probablemente colaboró a exterminar las especies aborígenes.

Las cinco sirenas que aparecen están tocando instrumentos musicales, cuatro son de cuerda (arpa, guitarra, vihuela y violín) y uno de viento (flauta). Hay que hacer notar que estos instrumentos son de uso masculino, y es interesante que no se ha representando la tinya o tambor que, en la vida cotidiana, puede ser usado por mujeres.

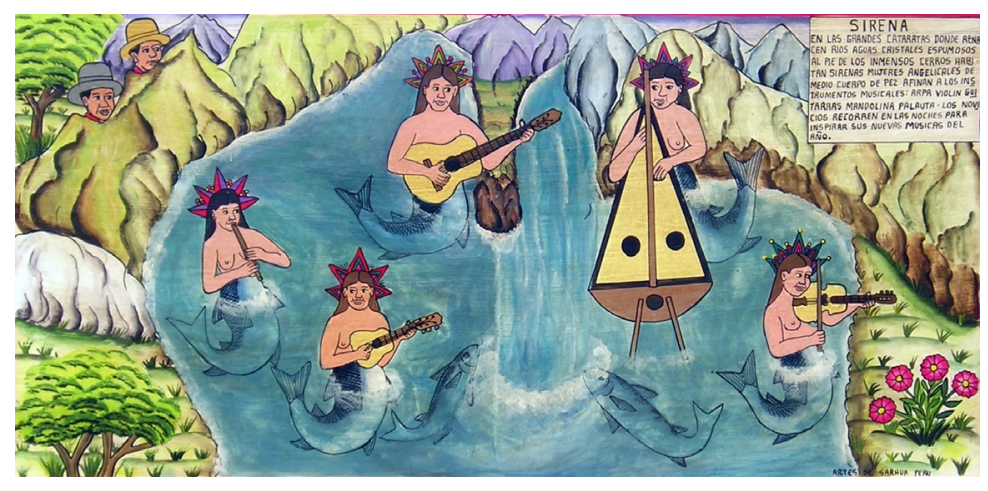

Dado que estas pinturas (miden alrededor de 30 x 60 centímetros) , que se conocen con el nombre de "tablas", fueron elaboradas por los pintores sarhuinos radicados en Iima, fue interesante pedir a los artistas que residen en Sarhua la interpretación de las imágenes hechas por sus paisanos en la capital. Al ver la que está dedicada a las sirenas, la interpretaron así:

... Donde hay cataratas, encantos [áreas de terreno en contacto con lo sobrenaturall, riadhelos o ríos grandes viven, dice. Ios pescadbs se canvierten en humanos, parte pescados parte humanos. Según yo escucho que cuenta la gente, lo llevan la gente sus instnmentos musicales: anpa, guitarra, quena y lo dejan en ese sitio, entonces ellos [las sirenas] sale [y] afinan los instnmentos y empiezan a tocar. [¿Usted ha hecho eso?] No, no. Según me dicen eso es [a las] dbce del día o dbce de la noche. Eso se hacía hace años, no es este tiempo. Incluso un tíomío lo había hedo o lo había visto. [Fre] enun encanto de altura, en Campaniyoq, en la laguma de altura que se Ilama 
Platococha. También se puede dejar los instnmentos en medio de los cerros para, quesuenenmejor. Ahí los diablos [como] también las sirenas afinan los instnmentos, [luego los músicos] los encuentran y empiezan a tocar. Ose enaventran con ellos [las sirenas] y empiezan a enseñarse... (entrevista a Pompeyo Berrocal Evanan. Sarhua, junio de 2004) .

Otro de los pintores, ahora también encargado de retocar las imágenes de la iglesia de Sarhua, nos dio su visión de la sirenas, luego de mirar atentamente la reproducción que llevamos.

Eso también he visto, es también un poco de imaginación, acá también en el cerro, más atrás está Platocochar es una laguna que parece un plato, allí hay un caída así [¿una cascada?] , sí, cayénobse así, una catarata, allí hay sirenas. [¿Alguien además las ha visto?] . No te sé decir, claro decían también los abuelos. Así en esta forma es la sirena [señalandb el dibajo] . Antes llevaban su anpa, violín, toobs sus instnumentos, 1 levaban los que querían tocar y los dejaban al borde de la laguna, entonces los dejan a la distancia, a cien, dbscientosmetros y vienen [las sirenas] y legritan, pues. Así [los instnumentos] estánbien afinaditos. Ellos [los músicos] han llevadb sus instnmentos, los jóvenes, el que desea tocar, el que toca la quena o guitarra o azpa o violín, los dejan, pero conmesa puesta [altar andino con ofrendas] : su florcita, su trago, su vino, su coca y no se que ctras casas. Io deja allí, y a media noche, entonces salen [las sirenas] y afinan los instnumentos y arandb [los músicos] necesitan los instnmentos, entances vanyya [los encuentran] bien afinaditos, para tocar només (entrevista a Porfirio Ramos Yanamé. Sarhua, junio de 2004) .

También consultamos al autor de la pintura, don Juan Walberto Quispe, sarhuino con residencia en Lima, que interpretó su obra de la siguiente manera:

Para ser un buen músico tiene que conocer un sitio que dicen que hay sirenas. Llevan instnumentos desafinadbs y los dejan allí una noche, al día siguiente regresan y el instrumento estábien afinadb y sólo arandb está bien afinado enser̃as o aprendes a tocar conmás faci7idad. Yése es el tera [de la "tabla"] , los obs jóvenes que aquí estánmiranob, estánmiranob si realmente es cierto, y para ellos sí, realmente las sirenas salen a tocar música. [¿Sólo se llevan los instrumentos para afinar?] Para aprender también, un músico para aprender debe afinar primero. El que quiere ser músico Ileva su instnmento y lo deja allí, dicen también que sabienob tocar, para que tenga mejor sonido o armonía el instnumento, lleva también. Puede 
ser nuevo cuando es para aprender, compran nuevo y llevan, o cuandb ya [saben] usado namás Ilevan.

Había un paisano sarhuino ¿conoces Sarhua? [Sí, he estado allí varias veces] Abajo hay un abismo que le Ilaman Ansari hayqo, no tiene un pase, se entra así un canalcito, por allí pasa agua. Allí había uno que tiene huerta, un duraznal, él por la noche había colgado su aupa al abismo para que lo tenga afinado, dice que toda la noche el anpa gritaba y al día siguiente [la] saca [estaba] suavecita para tocar, eso contaba el que tenía suhuertaallí.

[¿Por qué gritaba?] Creen que la sirena o el diablo lo tocaba. Sirena es como un diablo.

[En la tabla las dos personas están mirandb a las sirenas] Si las miras de frente, sentadb, no salen tampoco, tienes que mirarlas escondidb nanés. Tocas [las sirenas] sonmjeres, la sirena es una mjer, aquí están tocando la música una quena, una vihuela que es una guitarra chiquita, guitarra, ampa, violín.

Yono he visto nunca [a la sirena] . Esto [la tabla] es una imaginación, debe ser una bonita, una gringa, así una figura, medio avenpo de mujer, medio cuerpo de pez, las sirenas tienen en la cabeza una especie de corona, multicolor, que debe estar así. A Dios dibujan también con una corona de reo. Ios pescadbs son fami 7 ia de la sirena en el río, viven en una catarata, por eso esto es una catarata que está bajando (entrevista a Juan Wblberto Quispe Michae. Lima, enero de 2004).

La mirada de los sarhuinos incorpora el paisaje de su pueblo en la tradición generalizada en los Andes: la trucha se convierte en pariente de las sirenas, basta con un escaso curso de agua (dada la carencia de líquidb en la región) para establecer contacto con estos seres. Las flores que se retratan en la "tabla" son las mismas que ellos recogen a la orilla del río Qaracha o arroyos de altura. Pero esta percepción local no disminuye el énfasis que se encuentra en toda sirena andina: la vinculación de estos seres con la música.

Es importante recalcar el carácter sobrenatural de la criatura, que los sarhuinos se esfuerzan en mantener a distancia, a pesar de la necesidad de sus habilidades. Nótese que en dos de los testimonios, la sirena castiga, "hace gritar", a los instrumentos para "dejarlos suavecitos", proceso que puede compararse con el amansar del ganado. Este es un privilegio de los dioses. A los seres humanos no les está 
permitido maltratar ni siquiera a los enseres domésticos. Podría provocar la rebelión de los mismos, el tema es también tratado en otra "tabla" de los sarkuinos. (Millones, en prensa).

Si volvemos sobre el primer dibujo de Guaman Poma, debemos notar que las "sirenas" andinas, si bien viven en el agua, no siempre tienen la parte inferior en forma de pez, conformación que recogen los relatos orales sobre estos seres. A continuación copiamos un relato recogido por los maestros de Parinacochas en el SE del departamento de Ayacucho. Su redacción muestra el deseo de reelaborar el lenguaje de los informantes, pero, aun así, resulta importante para nuestro trabajo.

\section{Leyenda de Citan Paccha del caserío de Hual thua (Parinacochas, Ayacucho)}

Al noreste del caserío de Huallhua, encuéntrase una hermosa caída de agua, una cascada, que cae gota a gota resbalándose por entre las verdes y flotantes hojas de las plantas que crecen al borde de la peña. Aquellas gotas al desprenderse brill lan como puntos de oro al ser heridas por el sol y suenan como las notas de un concierto. Se reúne entre cortaderas y susurrando, con un ruido semejante al de las abejas que zumban en tomo a las flores, se alejan por entre las piedras y forman un cauce; luchan con los dostáculos que se oponen en su camino y se repliegan sobre sí mismas; saltan, luchan, huyen y corren, unas veces como risas, carcajadas, otras como suspiros, hasta formar un pequeño lago. En el lago caen como un numor indescriptible. Se oyen lamentos, palabras incoherentes, quejas, nombres, cantares y maravillas de misterio. Ia soledad con sus mil numores desconocidos, vive en aquel lugar y embriaga el espíritu en su inefable melancolía. En las plateadas hojas, en los huecos de las peñas, en las ondas del agua, parece que nos hablan invisibles espíritus. Pues en este pozo que simula un lago, vieron una mujer, vestida con ropas que se confundían con las olas cristalinas de las aguas, hermosa sobre toda ponderación. Sus cabellos eran como el oro; sus pestañas bri l laban como hilos de luz y entre las pestañas volteaban inquietas, unas pupilas seductoras. Luego despojándose de sus túnicas y sus velos, entraba y salía del agua, haciéndolas saltar en chispas luminosas sobre las flores de la margen, como una menuda lluvia de rocío, sacaba su cabeza de entre las hojas de una planta acuática, de la 
aal parecía una flor a medio abrir, ayo flexible tallo más bien se adivinaba en un continuo tambalear, debajo de los infinitos círculas de luz de las andas.

La bella sirena o ninfa de ese lugar atrae a los músicos y se dice que ella brinda a sus visitantes, conciertos deliciosos y con su voz celestial al cantar embarga a sus oyentes y con el arte de sus encantos, fascina a todos los amantes de la música.

Los danzantes, antes de ingresar a las fiestas, van a este lugar de Citan Paccoha, a entrenarse en el baile y realizar sus pruebas, y para mejor éxito, rinden culto a la deidad "Iranita", que así la llaman sus admiradbres" (Centro de colaboración... 1951: II, 291-292) .

Es interesante destacar que los pintores sarhuinos, tanto los que han radicado en Lima como los que permanecen en su pueblo, al referirse a las sirenas, las describan y las dibujen siguiendo el modelo occidental, tal como lo hace Guaman Poma en su pequeño diseño al lado del mapamundi. Pero otros testimonios orales, por ejemplo, aquellos que recogimos de los danzantes de tijeras, concuerdan con el de Huallhua: la sirena es una bella mujer que vive en el agua y cuyo cuerpo no tiene necesariamente la parte inferior pisciforme. Es probable que desde la presencia europea, los artistas andinos asuman como correcta la manera de retratarla, aunque la tradición oral mantenga la forma vigente del personaje que vive en los manantiales y ríos, y se refocila en las cascadas.

Esta relación con las aguas resulta significativa. El ser que posteriormente se identifica con la sirena occidental es el proveedor de sonidos que altera con su canto el conjunto de ruidos naturales que producen las aguas: el murmullo de la corriente, el brotar de los manantiales, la caída de las cascadas. Esa alteración, sin alejarse demasiado de los ruidos del agua o del viento, ya tiene forma musical y como tal es apreciada por los hombres, que descubren un grado diferente en los tonos que ofrece la naturaleza y los que ofrecen las sirenas. Como resultado de esta situación, estos seres acuáticos se convierten en los intermediarios entre la naturaleza y los seres humanos, que ganan este acceso al nuevo orden de los sonidos a costa del peligro de altemar con la sirenas. Todo relato sobre ella trae la precaución de advertimos que son seres demoníacos y que lidiar con 
ellos implica riesgo de muerte. Pero hay que vivir con el peligro si se quiere lograr la perfección en el arte. Es por eso que los músicos dejan sus instrumentos al borde de los puquios (manantiales) o a las orillas de arroyos o lagunas en los que el saber popular designa como habitación de sirenas. Al día siguiente, el arpa o violín sonará mucho mejor o las hojas de acero, conocidas como "tijeras" de los danzantes, tendrán un sonido estridente y melodioso.

"El bautizo de las tijeras es parte de un rito, vital e inseparable del danzante, porque de la música que desprenda, dependerá su vida... El danzante coloca las tijeras dentro del agua para "forjarlas" antes de que salga el sol y las cuelga en las peñas cuando se oculta, para que así escuchen las cosas que dice el viento y el agua"... (Rooríguez Amado 1995: 203) . En otras palabras, el sonido natural no es el sonido musical, es necesario alterar estos ruidos de la naturaleza para aprenderlos y modificarlos. Esto es lo que hacen las tijeras, primero se sumergen en el río o lago para captar su murmullo y luego, expuestas en las rocas, reciben el silbido o susurro del viento, su poder le permite usar estos elementos para hacer música. Hay que aclarar que de todas maneras el sonido musical no transforma radicalmente los sonidos de la naturaleza, mantiene una cierta dependencia que le permite seguirse nutriendo de ella. Por eso es necesario que los instrumentos de cuando en cuando hagan renovar su fuerza. Para decirlo con las palabras de una danzante de Angaraes: "Los viejos maestros creían que los músicos y los danzantes iban a la cueva [llamada Hirallanca, en la provincia de Acobamba] , porque antes destemplaban el violín, arpa y las tijeras, destemplaban totalmente, que el diablo o maestro [dentro de la cueva] afina los instnmentos" (Núñez $\mathrm{s} / \mathrm{f}: 50)$.

Esta conceptualización de la música y la presencia de las sirenas no parece variar a lo largo de los Andes. En el ayllu Macha al Norte de Potosí, en lo más intenso de la temporada de lluvias, desde fines de enero hasta el Carnaval, se recogen melodías nuevas. Una de sus fuentes proviene de los sonidos escuchados que surgen de las piedras - las cascadas de agua en que se dicen que viven los sirinus (sirenas) . "De veras, toda música, sea creada u obtenida, finalmente viene por medio de los sirinus, seres diabólicos, que habitan el mundo interior y emergen al mundo humano en esa época" (Stobart 1998: 583). 
En el pueblo de Qollana (Cuzco) se ha recogido un relato que atestigua la peligrosidad de la sirena. Cerca de un puquial vivía una de ellas, que en la noche tomaba la forma humana y hacía su música para seducir jóvenes. Cierta vez un muchacho caminaba por allí, pensando en su enamorada, de pronto se le apareció la sirena que con palabras dulces y música armoniosa lo invitó a su cueva. Como resultado de su aventura, el joven se enfermó y murió (Michaud 1970: 7-18) . Una situación similar nos describen Escalante y Valderrama (1977: 122-125), esta vez la sirena tiene la forma de una mujer joven que "hace llamar a los hombres cada vez que se antoja" . Los hombres seducidos por su reclamo "con sus propios pies" se arrojan al río y perecen. Ia sirena atrae a hombres y mujeres, pero a éstas las rechaza, sólo quiere dañar al otro sexo.

Como puede verse, las sirenas son en realidad seres malignos curya presencia es necesario evitar. Así nos lo dicen también los pintores de Sarhua que hemos entrevistado y en la "tabla" puede verse que los dos hombres que miran las sirenas lo hacen a hurtadillas, parapetados detrás de un montículo de tierra, a orillas del manantial.

Este intercambio con las fuerzas del más allá es una constante en la historia de la humanidad. El género humano adquiere la cultura a costa de sacrificio. En el propio Génesis, Adán y Eva pierden la vida eterna a cambio del conocimiento que les ofrece el Ánbol del Bien y del Mal. En otros mitos, es el intermediario quien sufre castigas o pérdidas, como en el mito de Prometeo o las aventuras del tlacuache mexicano. En el caso que estudiamos, se trata de una paso más delante de la adquisición general de la cultura, los músicos buscan el refinamiento de su arte, pero el precio sigue siendo igual. Para evitar esta desgracia existen estrategias. Ia sirena o demonio (la identificación la suelen hacer los pintores y músicas) puede ser engañada, a partir de un acuerdo formal, que es pasible evadir. Cuando se lleva un instrumento musical, los danzantes de tijeras suelen establecer un contrato por el que ceden su alma (que siempre se pierde junto con el cuerpo) a cambio de la musicalidad de sus instrumentos y la habilidad de tocarlos. Pero la fecha de cumplimiento se vence cuando se termina de llevar la cuenta de los años fijados. La trampa está en la forma de establecer la cifra de los mismos. 
El músico o danzante debe llevar al demonio un puñado de quinua, para contabilizar los años acordados en el cumplimiento del contrato, cada grano equivale a un año, cuando la sirena termine de contar los granos, arrastrará al músico a su morada. Pero no es fácil contarlos ya que pueden ser dispersados por el viento o caer por el suelo en momentos de sumarlos. Entonces, el demonio deberá empezar de nuevo a numerar los granos y la tarea puede ser infinita, el campesino puede envejecer y morir en este tiempo y el convenio quedará desecho.

El contrato frustrado es un tema universal. El hombre se ve forzado a establecer un acuerdo con las fuerzas ocultas para dominar el mundo en que vive, y perfeccionar su habilidad de hacerlo. Esta ambición de superar sus capacidades y la búsqueda de lograrlo a través de un convenio con el demonio tiene un relato paradigmático en la obra de Goethe. Fausto escribe con sangre el contrato que debió llevarlo a los infiemos, pero como sabemos, es rescatado en última instancia por los ángeles que dejan frustrado a Mefistófeles (Goethe 1951: III, 1357) .

El mismo tema de la búsqueda del saber infinito y el pacto con el demonio puede tener otros finales menos felices. Thomas Mann hace de su personaje, el músico Adrián Leverkühn, la víctima de su ambición, pero esta vez no acude la Providencia y muere mostrando en su rostro el lugar "donde se extinguió la llama del espíritu" (Mann 2001: 588) .

Los contratos de los músicos andinos revelan el mismo riesgo, pero la evasión del mismo no les llegará del cielo, sino de su ingenio para burlarse del convenio. No es probable que la evangelización española - la posterior hubiesen validado estos tratos con el demonio, pero aun aceptando que existiesen, la salvación sólo hubiese sido posible con la intervención divina. Un caso registrado en 1871 en el pueblo de San Pedro de Corculla, nos cuenta de un danzante de tijeras llamado Atanasio Ortiz. Involucrado en una situación semejante, su caso terminó cuando, a pesar de haberse arrepentido, fue perseguido por el demonio y hecho pedazos. (Olivas Escudero 1924: 425-427).

Las creencias al respecto no han cambiado. En 1984, cuando se fue a enterrar al famoso danzante Luz Rosoli de Parinacochas, en el "viaje camino al cementerio [que] es un poquito lejos, y aranob estábamos llevando a este bail larín, vino un cóndor por el aire y casi nos quita el ataúd del bailarín, porque el diablo estaba siguiéndblo, pues, así lo hemos enterrado esa tarde y al día siguiente supimos la noticia que después que lo hemas 
enterradb ya no había el cuerpo, no había nada en el ataúd, nada más estaba, pues, yel diablo se lo había llevado" (Nũ̃̃ez s/f: 42) .

El énfasis del catolicismo en considerar como perdidos todos los tratos con el más allá, contrasta con la visión indígena, en la que el demonio o sirena puede ser burlado por la habilidad del músico, cuya búsqueda del arte y la belleza parece justificar finalmente la ruptura del trato. Desde esta perspectiva, los artistas andinos no están lejos de las ambiciones de Fausto.

\section{Referencias bibliográficas}

CARTARI, Vincenzo (1996) : Le immagini degli dei Roma. Edizioni de Luca. Roma. CENTRO DE COLABORACIÓN PEDAGÓGICA PROVINCIAL (1951) . Monografía de la Provincia de Parinacochas. Nagisterio Primario de la Provincia de Parinacochas. Lima.

DURAND, José (1983) : Ocaso de manatíes. Fondo de Cultura Económica. México.

ESCALANIE, Carmen y Ricardo VAIDERRANA (1997) : La doncella sacrificada. Mitos del valle de colca. UNSA e IFEA. Arequipa.

GISBHRr, Teresa (1994) : Mitos prehispánicos en el arte. Editorial Gisbert y Cia. Ia Paz. GOEIHE, Johann Wolfgang (1951) : Obras completas. Aguilar. Madrid.

GUAMAN POMA DE AYALA, Felipe (1980) : El primer nueva corónica y buen gobiemo. John Murra y Rolena Adomo (editores) . Siglo XXI. México.

HOMERO (1956) : Odisea. Aguilar. Madrid.

MANN, Thomas (2001) : Doktor Faustus. Pocket Edhasa. Barcelona.

MICHALD, Andrés (1970) "La religiosidad Collana" en Allpanchis 2; pp. 7-18

MIIUNES, Luis (en prensa) : "La tabla del fin del mundo" en Represión, trasgresióny sentimientos en lahistoria altural andina.

NÚ̃̃EZ REBAZA, Lucy (s/f) : Los dansaq. Museo Nacional de la Cultura Penuana. Lima.

OLIVAS ESCUDERO, Fidel (1924) : Apuntes para la historia de Hhamanga. Imprenta Diocesana. Ayacucho.

OIDIO (1991) : Las metamorfosis. Editorial Juventud. Barcelona.

RODRÍGUEZ ANADO, Gustavo (1995) : Música en las fiestas del Perú. UNSA y UCSM. Arequipa.

STOBART, HENRI (1998) : "Lo recto y lo torcido: la música y la espiral de la descendencia" en Denise Y. Amold (compiladora) Cente de came y hueso. IICA /CIASE. La Paz, pp. 581-604. 